угорської меншини на території України, а також ринком на експорт, розвитком співпраці в безпековому секторі. Проте, прогнозування щодо наших відносин є неоднозначним, оскільки тут впливає багато факторів. Перший з них - російський вплив на іiі зовнішню політику. Хоча Угорщина є та позиціонує себе як незалежна та вільна держава, іiі дії спрямовані на підтримку свого напряму політики, але не можна не помітити російського втручання та проросійського бачення, приклади якого наведені вище. Другий з важливих - співпраця безпосередньо України та Угорщини. Тільки двосторонні поступки та взаємодія допоможуть вийти 3 кризи та налагодити позитивні та дружні відносини між обома країнами.

\title{
Література:
}

1. Сергій Герасимчук. Які держави вважають «дружніми», а які ні, та чи остаточно Україна відвернулася від Росії? Украӥнська призма. 2021. URL: http://prismua.org/09-01-2021-2/.

2. Потіха А. Українсько-угорські відносини в контексті візиту глави МЗС Угорщини. Україна: подіï, факти, коментарі. 2021. № 2. C. 4-11. URL: http://nbuviap.gov.ua/images/ukraine/2021/ukr2.pdf.

3. Глава МЗС Угорщини поскаржився у ПАРС на український «Миротворець». Украӥнська правда. 2021. URL: https://www.pravda.com.ua/news/2021/06/21/7297969/.

4. Юрій Братюк. Угорщина заблокувала заяву Вишеградської групи 3 критикою агресії РФ. ZAXID.NET. 2021. URL: https://zaxid.net/ ugorshhina_zablokuvala_zayavu_vishegradskoyi_grupi_z_kritikoyu_rosiysk oyi_agresiyi_n1518064.

\section{DOI https://doi.org/10.30525/978-9934-26-120-6-15}

\section{ЗБРОЙНІ КОНФЛІКТИ ЯК КРИЗА СВІТОВОЇ КОМУНІКАЦЇ̈}

\author{
Лікарчук Д. С. \\ кандидат політичних наук, \\ дочент кафедри міжнародних відносин \\ Київський начіональний університет культури і мистецтв \\ м. Київ, Украӥна
}

Динаміка сучасних міжнародних відносин, нові модернізаційні процеси та глобальні виклики сучасного світу потребують нового осмислення поняття «збройні конфлікти». Відповідно до останніх 
світових подій, ми можемо стверджувати, що минулі тактики, стратегії, механізми проведення збройних конфліктів відрізняються від сучасних.

Європейські науковці наголошують на тому, що традиційне поняття «війна», з юридичної точки зору, є застарілим для сучасності й варто застосовувати такий термін як «міжнародні військові конфлікти». Адже даний термін більш чіткіше відповідає сучасним реаліям та включає в себе нові механізми.

Загально доступне визначення міжнародного збройного конфлікту надано в Протоколі №1 1977-го року - додатковому до чотирьох Женевських конвенцій [1] від 1949-го року. В міжнародному гуманітарному праві розрізняють два типи збройних конфліктів:

- міжнародний збройний конфлікт під час якого мають протистояння дві або більше держав;

- неміжнародні збройні конфлікти між урядовими силами та збройними групами [1].

Останнім часом ми можемо прослідкувати інтернаціоналізовані конфлікти - конфлікти, які поєднують в собі ознаки як внутрішнього, так і зовнішнього конфліктів. Свропейські науковці, відзначають, що необхідно посилити дослідницьку діяльність щодо норм міжнародного права [5, с. 87], особливо в сфері неміжнародних збройних конфліктів, а найбільше в сфері інтернаціоналізації. Свропейські інституції зможуть надати допомогу державам в яких й відбулося поєднання як внутрішніх, так і зовнішніх конфліктів.

Відповідно до останніх світових подій, ми можемо стверджувати, що одним з елементів збройних конфліктів - $\epsilon$ міжнародний тероризм. Як відзначає Барбра Волтер [7, с. 471], акти тероризму всередині держави, можуть бути не лише наслідком не правильної політики самої держави, але $\epsilon$ втручанням в цю державу міжнародних акторів.

Знову ж таки розгляд членів міжнародних терористичних організацій як учасників та суб'єктів збройних конфліктів на сьогоднішній день не просто потребує переосмислення, а й чіткого трактування в міжнародному праві.

Новим поняттям, яке відображається в міжнародно-правовому аспекті є «інформаційні війни», один з різновидів збройних конфліктів. Канадський правознавець Кеннет Уоткін [8, с. 23] відзначає, що такого роду конфлікти призводять до проблем визначення статусу суб'єктів таких конфліктів, які також відбуваються через «клавіатуру» (Інтернет). В даному випадку, ми говоримо про те, що навіть онлайн дії в Інтернеті, які спонукають до терористичних вчинків - також $\epsilon$ збройним конфліктом. Ми погоджуємось 3 європейськими та американськими науковцями, про те, що інформація також є зброєю. 60 
Сьогодні постає питання щодо юридичних нормах - як слід трактувати та осмислювати такі поняття як «війна», «збройний конфлікт міжнародного характеру» та «збройний конфлікт не міжнародного характеру» $[4$, с. 96]. Як відзначено вище, відповідно до міжнародного правової регламентації, розгляд наведених понять відбувається у межах кваліфікації збройних конфліктів.

Звертаємо увагу на те, що відповідно до статті другої Женевських конвенцій 1949-го року: «Крім положень, які виконуються в мирний час, ця Конвенція застосовується в усіх випадках оголошеної війни чи будь-якого іншого збройного конфлікту, що може виникнути між двома чи більше Високими Договірними Сторонами, навіть якщо стан війни не визнаний однією 3 них» [1]. Тут чітко визначається що конфлікт відбувається між державами, адже під «Високими Договірними Сторонами» ми розуміємо суверенних акторів міжнародної політики.

Що стосується поняття не міжнародного збройного конфлікту, в міжнародному гуманітарному праві, тут ми відзначаємо третю статтю Женевських конвенцій та статтю № 1 додаткового протоколу 1977 року. Саме такі нормативні акти регулюють комунікативні стосунки між конфліктуючими держави.

В даному випадку варто відзначити, що $з$ другої половини XX-го століття поняття «війна» не є частиною правової сфери, - відбувається заміна на категорію «збройний конфлікт» [2, с. 140]. Спостерігаємо такий процес, коли саме термін «війна» набуває суто політико-правової категорії. Це вплинуло на те, що в світовій практиці при розгляді тих чи інших ситуацій збройного протистояння між державами використовують нейтральне поняття «збройного конфлікту». Така міжнародна особливість є притаманною не лише міжнародному гуманітарному праву, а й в певній мірі діяльності Організації Об'єднаних Націй [3, с. 37].

Війна й збройний конфлікт також розглядаються як одна з безлічі форм прояву кризи, для якої характерно:

- загроза цінностям - життю, приватній власності, демократії, безпеці, сувернітету;

- відчуття невизначеності - коли майбутні тенденції й події виглядають важкопередбачуваними та динамічними;

- жорсткі часові рамки, оскільки ясно, що чим довше тривають події даного типу, тим гіршими будуть наслідки [6, с.117].

Причому характеристика збройного конфлікту як «оборонної стратегії», та «реалізації права на самооборону» не носять «кваліфікації» при застосуванні терміна «війна». Це може бути війна, в 
тому числі й агресивна, але 3 дотриманням формальних вимог, зазначених вище. Складно назвати дії США в Іраку оборонною війною, проте формальні вимоги, як оголошення - були виконані.

Слід зазначити, що суб'єктам збройних конфліктів (державам) потрібно бути готовими до ситуацій можливої «несподіваної», раптової переорієнтації найважливіших світових центрів прийняття рішень 3 однієї загальної політичної логіки дії на іншу, зокрема (в одному 3 геополітичних вимірювань) - 3 мондіалістскої логіки на логіку пріоритету національних інтересів держави (конкретної країни) або «групового егоїзму» кількох держав.

\section{Література:}

1. Geneva Convention for the Amelioration of the Condition of the Wounded and Sick in Armed forces in the Field: Commentary International Committee of the Red Cross. Geneva, 1952.

2. Hyslop M. Obstructive Marketing: Restricting Distribution of Products and Services in the Age of Asymmetric Warfare. Gower Publishing Ltd.: Ashgate, 2014. - 347 p.

3. Likarchuk D. The role of international organisations in the settlement of foreign policy conflict. International Relations, 2020. pp. 35-44

4. Simons G. Islamic Extremism and the War for Hearts and Minds. Global Affairs. 2016. Pp. 91-99.

5. Payne K. The Media as an Instrument of War. Parameters.Spring 2005. Pp. 81-93.

6. Waller J. M. Fighting the War of Ideas Like a Real War. Washington, DC: The Institute of World Politics Press, 2007. - 149 p.

7. Walter B. The new new civil wars. Annual Review of Political Science. V. 20. 2017. P. 469-486.

8. Watkin K. Controlling the Use of Force: A Role for Human Rights Norms in Contemporary Armed Conflict The American Journal of International Law Vol. 98, №. 1 (Jan., 2004). Pp. 1-34 